\title{
Fault-Plane Solution of the Earthquake of 19 March 2005 in Monatele (Cameroon)
}

\author{
Eric N. Ndikum 1,2*, Charles T. Tabod1, Alain-Pierre K. Tokam1, Bernard Z. Essimbi1 \\ ${ }^{1}$ Department of Physics, University of Yaoundé 1, Yaoundé, Cameroon \\ ${ }^{2}$ Department of Fundamental Sciences, Higher Technical Teacher Training College (H. T. T. T. C.) \\ Bambili-Bamenda, The University of Bamenda, Bambili, Cameroon \\ Email: ndikumeric@yahoo.com
}

Received 26 April 2014; revised 22 May 2014; accepted 17 June 2014

Copyright (C) 2014 by authors and Scientific Research Publishing Inc.

This work is licensed under the Creative Commons Attribution International License (CC BY). http://creativecommons.org/licenses/by/4.0/

(c) (i) Open Access

\begin{abstract}
An earthquake of magnitude $\mathrm{Ml}=3.04$ was detected on the 19 of March 2005 at 11:49:18.31 (local time) by seven broadband seismometers located around Cameroon (Central Africa). Its epicenter has been relocated and found to be in Monatele (Cameroon) with latitude $4^{\circ} 26.34$ ' and longitude $10^{\circ} 59.62 '$. The fault-plane solution calculated using double couple fault-plane solutions based on P-wave polarity readings, also taking into consideration the dextral nature of the Sanaga Fault (SF) underlying this region of the epicenter, is a strike-slip fault with a normal faulting component. The beach ball representation of this fault-plane solution has strike, dip and rake values of 289, 70, -169 for the principal fault plane and $195,80,-20$ for the auxiliary fault plane.
\end{abstract}

\section{Keywords}

Earthquake, Monatele, Epicenter, Fault Plane Solution, Strike-Slip Fault, Normal Faulting, Component

\section{Introduction}

On the $19^{\text {th }}$ of March 2005, an earthquake occurred in the Center Province of Cameroon and the preliminary location of this earthquake situated it at a latitude of $4^{\circ} 10.86^{\prime}$, a longitude of $11^{\circ} 1.38^{\prime}$ with a depth of $10 \mathrm{~km}$ by the US National Earthquake Information Center (NEIC); and at a latitude of $4^{\circ} 12.74$ ', a longitude of $11^{\circ} 6.28^{\prime}$ with a depth of $10 \mathrm{~km}$ by the International Seismological Center (ISC) [1]. The effect of this earthquake was felt some about $81 \mathrm{~km}$ in the vicinity of Yaounde, the capital city of Cameroon. At the moment of the occurrence of the earthquake, a temporary deployment of 8 broadband seismic stations was operating across Cameroon [2] in order

\footnotetext{
${ }^{*}$ Corresponding author.
}

How to cite this paper: Ndikum, E.N., Tabod, C.T., Tokam, A.-P.K. and Essimbi, B.Z. (2014) Fault-Plane Solution of the Earthquake of 19 March 2005 in Monatele (Cameroon). Open Journal of Geology, 4, 289-293. 
to study the Cameroon Volcanic Line (CVL) which is one of the most intriguing geological features in West Africa. In this current study, records from 7 stations of this deployment were used to relocate the epicenter of this earthquake in Monatele, the divisional headquarters of the Lekie Division of the Center Region of Cameroon. When the different alignments of fault lines in Cameroon are considered, Monatele is located along the SW section of the Sanaga Fault which is the source of this earthquake (Figure 1).

\section{Methodology}

\subsection{Data Acquisition}

This earthquake was detected by the following broadband seismometers: CM06, CM09, CM18, CM24, CM26, CM29 and CM32 (Figure 2 and Figure 3); located around Cameroon. These seismometers were among 8 portable broadband seismometers installed in January 2005 and used in the Cameroon Broadband Seismic Experiment to study the Cameroon Volcanic Line-CVL [2]. These 7 seismometers were constituted of two (2) Guralp CMG-3T seismometers, one (1) Guralp CMG-3ESP seismometer and four (4) Streckeisen STS-2 seismometers. They recorded data continuously at 40 samples per second [3].

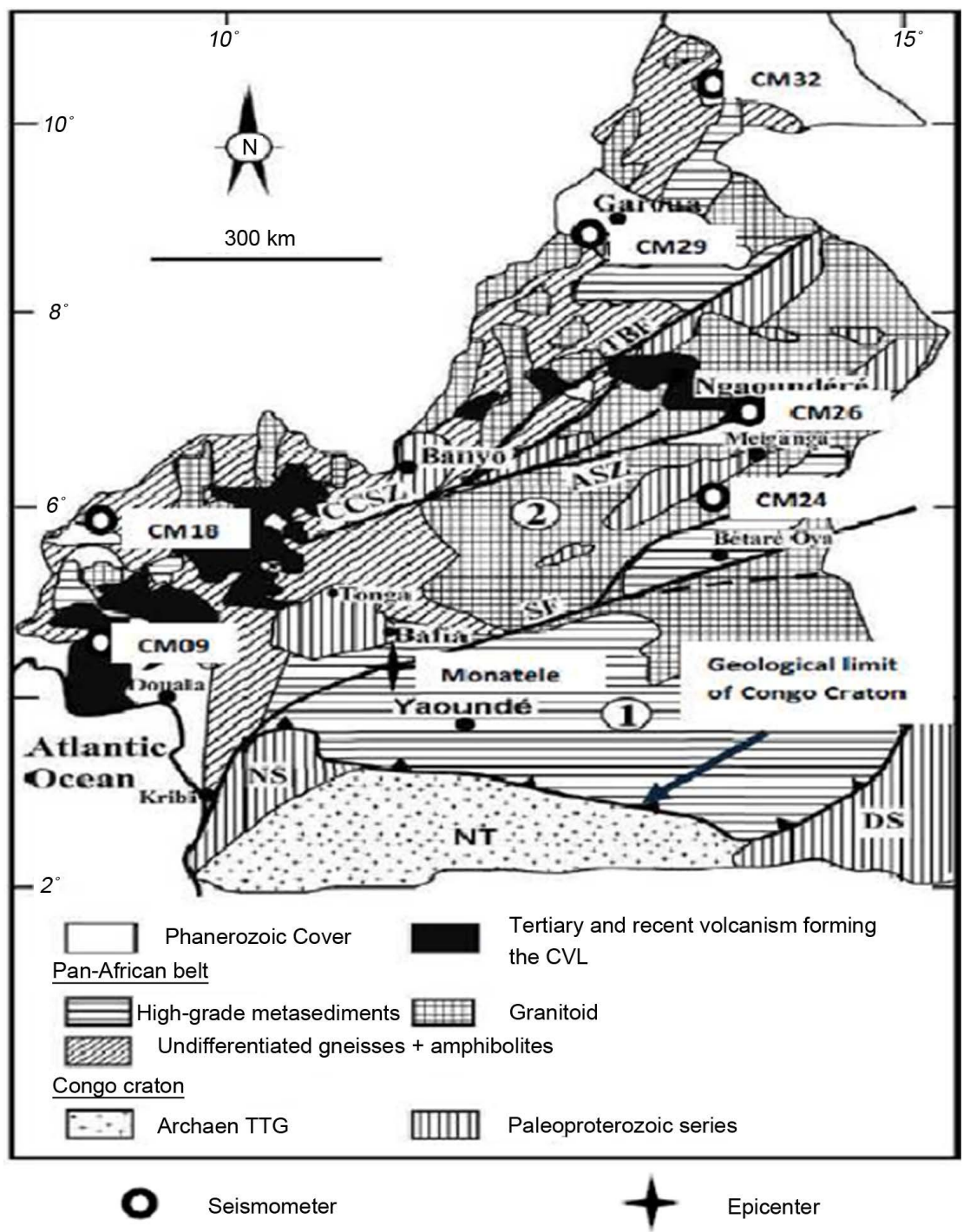

Figure 1. Position of the Sanaga Fault (SF) and Monatele on the map of Cameroon. The star indicates the position of Monatele (the epicenter of the earthquake) and the arrow points to the Geological limit of the Congo Craton (adapted from [4]). 


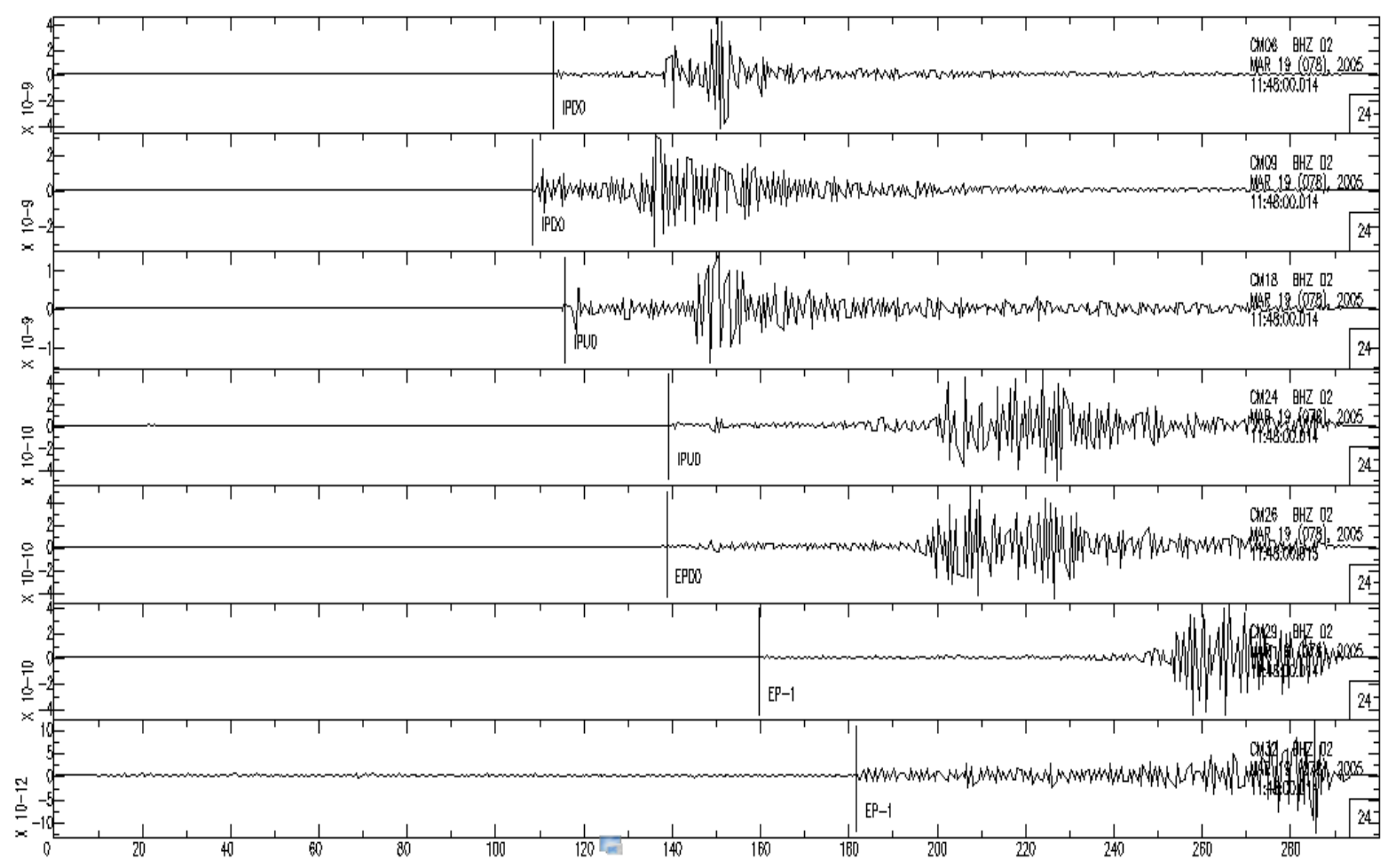

Figure 2. First arrivals of earthquake (indicated by vertical black lines) registered at stations CM09, CM06, CM18, CM24, CM26, CM29 and CM32. (First arrivals are labeled with four characters which represent; nature of onset phase: I = impulsive or $\mathrm{E}$ = emergent (first character), type of first arrival phase used: either P or S (second character), direction of first arrival: either $\mathrm{U}=$ up or $\mathrm{D}=$ down or- = not clear (third character), quality of phase: ranging from $0=$ highest quality to $4=$ lowest quality (fourth character).

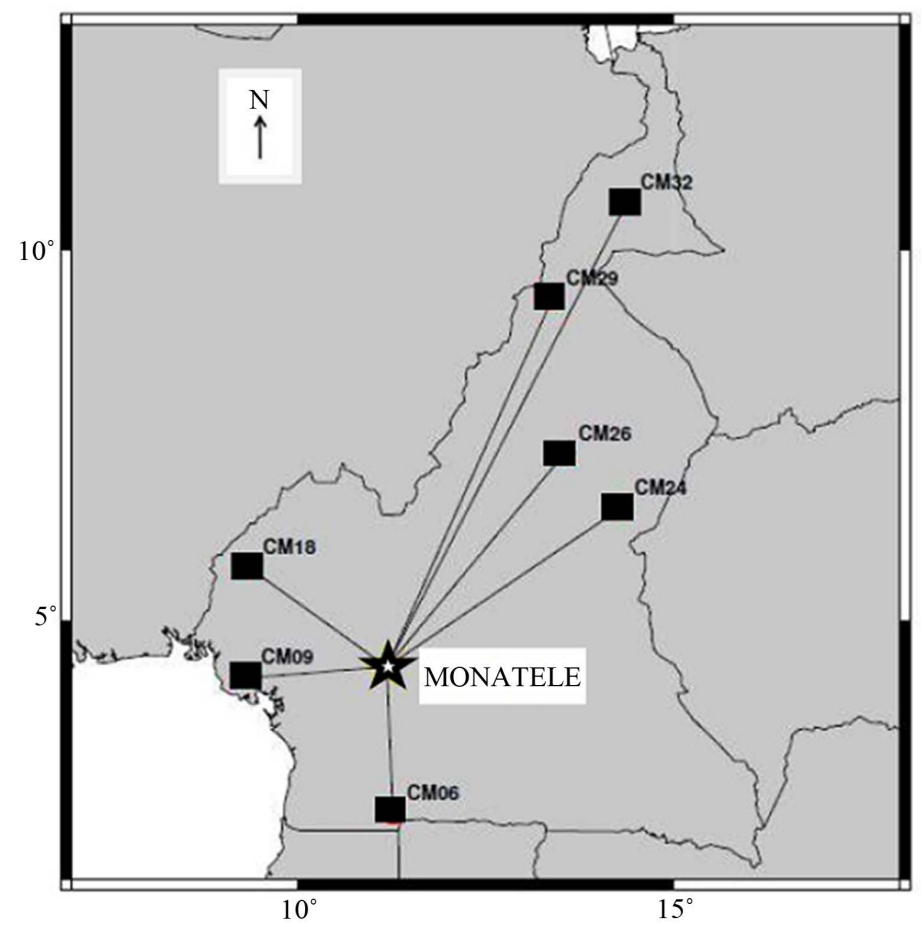

Figure 3. Plot of great circle path (GCP) between epicenter of event (star) and stations (squares). 


\subsection{Locating the Earthquake}

Data from the different stations in miniseed format were converted to the Seismic Analysis Code (SAC) format. The SAC program was used to filter the events (using a butterworth filter with two poles and corner frequencies of 0.5 and $2 \mathrm{~Hz}$ ), pick first arrivals, determine their polarities and obtain the maximum amplitude of the event. This information was then used to build the input file for the earthquake location program HYPOINVERSE [5]. The results from this location program stored in an archive output file showed that this earthquake has its epicenter at Monatele (Figure 3) with latitude $4^{\circ} 26.34^{\prime}$ and longitude $10^{\circ} 59.62^{\prime}$; and its focus at a depth of about 7 $\mathrm{km}$. The program also determined the azimuths and takeoff angles of the events (Table 1).

\subsection{Determination of Fault Plane Solution}

The archive output data of HYPOINVERSE was used as an input file into the computer program FPFIT by Reasenberger and Oppenheimer [6] which calculates double couple fault-plane solutions based on P-wave polarity readings. The program was used to generate possible fault-plane solutions allowing room for multiple solutions to be presented. The resulting solution was then plotted using FPFIT program to yield the fault-plane solution in a beach-ball representation (Figure 4).

\section{Discussion of Results}

The beach ball brought out two fault planes with strike, dip and rake values of $289,70,-169$ and 195, 80, -20 respectively. Previous studies in the region suggested that the Sanaga Fault is a dextral fault [7]-[9]. Therefore, considering the orientation of the two fault planes in the beach ball representation of the fault-plane solution generated with FPFIT (see Figure 4), the fault plane with strike, dip and rake values of 289, 70, -169 is oriented such that the solution is dextral. Consequently, the principal fault plane is that with strike, dip and rake values of $289,70,-169$; while the other fault plane constitute the auxiliary plane. When beach ball representation of fault plane solutions are taken into consideration, the beach ball solution generated from this earthquake also suggests that this fault is a strike-slip fault with a normal faulting component.

\section{Conclusion}

The local earthquake of $19^{\text {th }}$ March 2005 of magnitude $\mathrm{Ml}=3.04$ was located by the computer-aided program

Table 1. Output archive data from HYPOINVERSE showing earthquake location information (retyped and not to scale by author for the purpose of clarity and presentation). Line 1 gives a summary of the location information (time/date: 19/03/2005 at 11:49:18:31, latitude: $4^{\circ} 26.34^{\prime}$, longitude: $10^{\circ} 59.62^{\prime}$, ....). From lines 3 to 9: column 1 gives station name (as first four characters), nature of onset phase: $\mathrm{I}$ = impulsive or $\mathrm{E}=$ emergent (fifth character), type of first arrival phase used: either $\mathrm{P}$ or $\mathrm{S}$ (sixth character), direction of first arrival: either $\mathrm{U}=$ up or $\mathrm{D}=$ down or $-=$ not clear (seventh character), quality of phase: ranging from $0=$ highest quality to $4=$ lowest quality (eighth character); column two gives event date and time of event; column eleven gives the takeoff angles of the events for the stations in the first two characters; column fourteen contains the azimuth to station of the event and the last column gives the component of the SAC signal used (first three characters being the $\mathrm{Z}$ component of the broadband seismometer) and the seismic network used (last two characters).

\begin{tabular}{|c|c|c|c|c|c|c|c|c|c|c|c|c|c|c|c|c|c|c|c|}
\hline 05031911491831 & \multirow{2}{*}{$\begin{array}{l}4 \quad 2634 \\
7 X\end{array}$} & \multicolumn{2}{|c|}{105962} & 7063 & \multicolumn{2}{|c|}{413018630} & \multicolumn{3}{|c|}{30124892745304} & \multirow[t]{2}{*}{240} & \multirow[t]{2}{*}{0} & \multirow[t]{2}{*}{172} & \multirow[t]{2}{*}{-} & \multirow[t]{2}{*}{0} & \multicolumn{2}{|c|}{2402745} & \multirow[t]{2}{*}{7} & \multirow[t]{2}{*}{70} & \multirow[t]{2}{*}{$\begin{array}{ll}0 & 11\end{array}$} \\
\hline 0CMX a & & $\begin{array}{ll}0 & 0 \mathrm{I}\end{array}$ & L304 70 & & & X304 & 70 & 0 & & & & & & & & & & & \\
\hline CM09IPD0 & 0503191149 & 4600 & 34110 & 0 & 0 & 0150 & 0 & 0 & 01863 & 5200 & 60 & 0 & 96 & 030 & 999 & 0 & a & $\mathrm{X}$ & BHZXB \\
\hline CM06IPD0 & 0503191149 & 5100 & -15110 & 0 & 0 & 0902 & 0 & 0 & 02292 & 5200 & 20 & 0 & 188 & 035 & 999 & 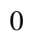 & a & $\mathrm{X}$ & BHZXB \\
\hline CM18IPU0 & 0503191149 & 5100 & -34110 & 0 & 0 & 086 & 0 & 0 & 02306 & 5200 & 60 & 0 & 51 & 030 & 999 & 0 & 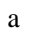 & $\mathrm{X}$ & BHZXB \\
\hline CM26EPD0 & 0503191149 & 7600 & 3469 & 6000 & 0 & 061 & 0 & 0 & 04216 & 5000 & 2 & 0 & 318 & 030 & 999 & 0 & 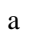 & $\mathrm{X}$ & BHZXB \\
\hline CM24IPU0 & 0503191149 & 7800 & 1050 & 6000 & 0 & 044 & 0 & 0 & 04319 & 5000 & 50 & 0 & 303 & 036 & 0 & 0 & a & $\mathrm{X}$ & BHZXB \\
\hline CM29EP-1 & 0503191149 & 9600 & -2430 & 6000 & 0 & 033 & 0 & 0 & 06038 & 5000 & 30 & 0 & 335 & 036 & 0 & 0 & $\mathrm{~d}$ & $\mathrm{X}$ & BHZXB \\
\hline CM32EP-1 & 0503191149 & 12300 & 2690 & 12000 & 0 & 010 & U & 0 & 07788 & 5000 & 10 & 0 & 332 & 029 & 0 & 0 & $a$ & $\mathrm{X}$ & BHZXB \\
\hline
\end{tabular}




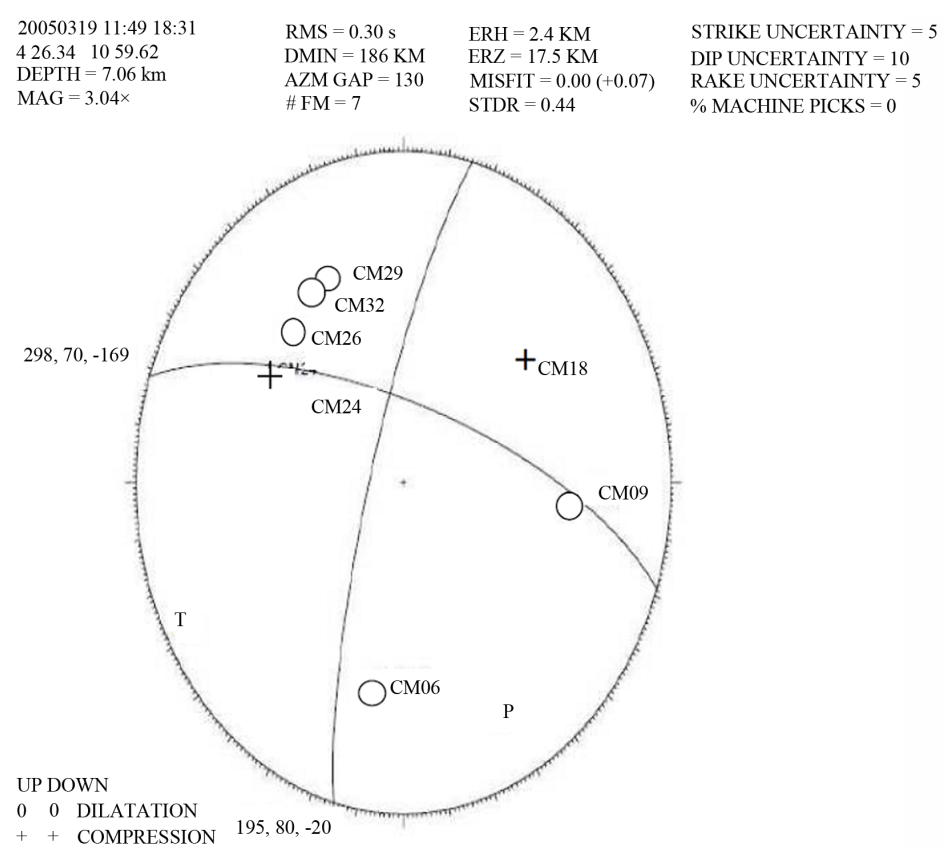

Figure 4. Beach-ball representation of the fault-plane solution of the Monatele earthquake.

HYPOINVERSE to have epicenter at Monatele (in Cameroon) situated at latitude $4^{\circ} 26.34^{\prime}$ and longitude $10^{\circ} 59.62$ '. This earthquake is seen to have a source the underlying Sanaga Fault. The fault-plane solution obtained by the help of the computer program FPFIT suggests that the section of the Sanaga Fault (SF) around this region is a strike-slip fault with a normal faulting component. Nevertheless, more accuracy would have been added to these results if more stations had recorded this event and their signals processed.

\section{References}

[1] Incoporated Research Institution for Seismology (IRIS) (2005) On-Line Bulletin. http://www.iris.washington.edu/SeismiQuery/bin/eventsmag.pl

[2] Euler, G.G., Wiens, D.A., Shore, P., Koch, F.W., Tibi, R., Nyblade, A.A. and Reusch, A.M. (2008) Shear Velocity Structure of the Cameroon Volcanic Line Region from Rayleigh Wave Phase Velocities. EOS, Transactions, American Geophysical Union, AGU Fall Meeting Suppl., 89, Abstract \#S21C-1843.

[3] Tokam, K.A.P., Tabod, C.T., Nyblade, A.A., Julia, A., Weins, D.A. and Pasyanos, M.E. (2010) Structure of the Crust beneath Cameroon, West Africa, from the Joint Inversion of Rayleigh Wave Group Velocities and Receiver Functions. Geophysical Journal International, 183, 1061-1076. http://dx.doi.org/10.1111/j.1365-246X.2010.04776.X

[4] Ngnotue, T., Ganno, S., Nzenti, J.P., Schulz, B., Tchaptchet, T.D.I. and Suh, C.E. (2012) Geochemistry and Geochronology of Peraluminous High-K Granitic Leucosomes of Yaoundé Series (Cameroon): Evidence for a Unique PanAfrican Magmatism and Melting Event in North Equatorial Fold Belt. International Journal of Geosciences, 3, 525548. http://dx.doi.org/10.4236/ijg.2012.33055

[5] Klein, F.W. (2002) Hypocenter Location Program HYPOINVERSE. US Geological Survey Open File Report 02-171, Version 1.0 .

[6] Reasenberg, P.A. and Oppenheimer, D. (1985) FPFIT, FPPLOT and FPPAGE: FORTRAN Computer Programs for Calculating and Displaying Earthquake Fault-Plane Solutions. US Geological Survey Open-File Report 85-739, 109 p.

[7] Dumont, J.F. (1986) Identification par Télédétection de L’accident de la Sanaga (Cameroun). Sa Position dans le Contexte des Grands Accidents D’Afrique Centrale et de la Limite Nord du Craton Congolais. Géodynamique, 1, 13-19.

[8] Bisso, D., Mangeulle-Dicoum, E., Ndougsa, M., Tabod, C.T., Jandjock, N.P., Njinti, N., Tadjou, J.M. and Essono, J. (2004) Geophysical Determination of the Sanaga Fault Using Audio-Magnetotelluric Soundings in the Ebebda Region, Cameroon (Central Africa). Segmite International, 1, 46-49.

[9] Poudjom, D.Y.H., Nnange, J.M., Diament, M., Ebinger, C.J. and Fairhead, J.D. (1995) Effective Elastic Thickness and Crustal Thickness Variation in West Central Africa Inferred from Gravity Data. Journal of Geophysical Research, 100, 22047-22070. http://dx.doi.org/10.1029/95JB01149 